\title{
ANALISA KEBUTUHAN AIR BERSIH UNTUK OPERASIONAL HARIAN DAN SISTEM PEMADAM KEBAKARAN SPRINKLER GEDUNG UTAMA BARU RUMAH SAKIT BHAYANGKARA PALEMBANG
}

\author{
R.A. Sri Martini'), Erny Agusri' ${ }^{1)}$, dan M. Nur Ridho Hasan" ${ }^{1)}$ \\ 1) Program Studi Teknik Sipil, Fakultas Teknik, Universitas Muhammadiyah Palembang, \\ Sumatera Selatan \\ ninikkunc@gmail.com
}

\begin{abstract}
The Bhayangkara Hospital Palembang has the main building with four floors and about $6102.52 \mathrm{~m}^{2}$ building area and $7538 \mathrm{~m}^{2}$ surface area. It has 173 beds, 45 toilets, and 369 employees. In the new building, there are 3 water sources, which are the tank fiberglass panels with the capacity of $403 \mathrm{~m}^{3}$ and $90 \mathrm{~m}^{3}$, and a roof tank with the capacity of $16 \mathrm{~m}^{3}$. With the additional building, the water needs are also increased in order to fulfil the daily operational water needs and the new main building's sprinkler fire extinguisher system. The purpose of this study is to know the amount of water that must be provided for the daily operational. Analysis methods and data processing in this study are descriptive analysis methods, which the existing data are separated from the data with a form of numbers, either there are primary or secondary data. The data analysis includes: the maximum clean water needs for the daily operational based on the amount of patient's bed (500 liter/bed/day), the hospital's employees (120 liter/person/day), toilets (39 liter/day), sinks (30 liter/day), urinals (30 liter/day), showers (75 liter/day), and janitors (0.5 liter $/ \mathrm{m}^{2} /$ day), and the water needs from the sprinkler fire extinguisher system. Based on the calculations, the maximum clean water needs for daily operation is $132749 \mathrm{~m}^{3} /$ day and the water needs for the sprinkler fire extinguisher is $992.358 \mathrm{~m}^{3}$ for 30 minutes, while the available amount of clean water is $146 \mathrm{~m}^{3} /$ day. It can be concluded that the Bhayangkara Hospital's water sources can only fulfilled the hospital's daily operational water needs. Then, there will be plans to make the bigger volume of the ground water tank for $1.120 \mathrm{~m}^{3}$.
\end{abstract}

Keywords: Bhayangkara Hospital Palembang, operational and sprinkler water needs, ground water tank 


\begin{abstract}
ABSTRAK
Rumah Sakit Bhayangkara Palembang mempunyai gedung utama baru dibangun dengan 4 lantai dengan luas bangunan $\pm 6102.52 \mathrm{~m}^{2}$ dan luas tanah $7538 \mathrm{~m}^{2}$ yang memiliki 173 tempat tidur inap, 45 toilet dan 369 pegawai. Pada bangunan gedung baru terdapat 3 sumber air yaitu panel tank fiberglass berkapasitas $40 \mathrm{~m}^{3}$, panel tank fiberglass berkapasitas $90 \mathrm{~m}^{3}$, dan roof tank berkapasitas $16 \mathrm{~m}^{3}$. Dengan penambahan gedung maka kebutuhan air pun meningkat, untuk memenuhi kebutuhan air operasional harian dan untuk sistem pemadam kebakaran sprinkler gedung utama baru. Tujuan penelitian ini untuk mengetahui jumlah air yang harus disediakan untuk operasioanl tersebut. Metode analisa dan pengolahan data yang digunakan dalam penelitian ini adalah metode analisis deskriptif dimana data yang ada dipisahkan dari data yang berbentuk angka baik dari data primer maupun data sekunder. Analisa data meliputi: kebutuhan air bersih untuk operasional harian maksimumberdasarkan jumlah tempat tidur pasien (500 liter/bed/hari) jumlah pegawai rumah sakit (120 liter/orang/hari), jumlah toilet (39 liter/hari), wastafel (30 liter/hari), peturasan (30 liter/hari), shower (75 liter/hari), dan janitor (0.5 liter $/ \mathrm{m}^{2} / \mathrm{hr}$ ) dan kebutuhan air sistem pemadam kebakaran sprinkler. Dari hasil perhitungan didapat kebutuhan air bersih untuk operasional harian maksimum berjumlah $132.749 \mathrm{~m}^{3} /$ hari dan kebutuhan air sistem pemadam kebakaran sprinkler berjumlah $992.358 \mathrm{~m}^{3}$ selama 30 menit sedangkan jumlah air bersih yang tersedia berjumlah $146 \mathrm{~m}^{3} /$ hari. Dengan demikian dapat disimpulkan bahwa sumber air Rumah Sakit Bhayangkara Palembang hanya mampu memenuhi kebutuhan air operasional rumah sakit. Maka direncanakan volume kapasitas ground water tank sebesar $1120 \mathrm{~m}^{3}$.
\end{abstract}

Kata kunci: Rumah Sakit Bhayangkara Palembang, kebutuhan air operasional dan sprinkler, ground water tank 


\section{PENDAHULUAN}

Rumah Sakit Bhayangkara

Palembang adalah rumah sakit milik POLRI dan termasuk kedalam rumah sakit dengan kelas C bertempat di Jalan Jendral Sudirman Km 4.5 Palembang. Rumah Sakit Bhayangkara Palembang mempunyai gedung utama baru dibangun dengan 4 lantai dengan luas bangunan $\pm 6102.52 \mathrm{~m}^{2}$ dan luas tanah $538 \mathrm{~m}^{2}$ yang memiliki 173 tempat tidur inap, 45 toilet dan 369 pegawai, baik itu pegawai medis dan non medis.

Rumah Sakit Bhayangkara Palembang mempunyai 3 sumber air yaitu panel tank fiberglass berkapasitas $40 \mathrm{~m}^{3}$, panel tank fiberglass berkapasitas $90 \mathrm{~m}^{3}$, dan roof tank berkapasitas $16 \mathrm{~m}^{3}$. Dalam pembangunan sebuah gedung bertingkat penting adanya sistem penyediaan air bersih untuk memenuhi kebutuhan operasional kerja pada gedung tersebut serta adanya fasilitas pengamanan terhadap bahaya kebakaran.

Dengan adanya sistem pemadam kebakaran atau fire fighting system dibutuhkannya ketersediaan air yang harus selalu siap sedia kapanpun dibutuhkan. Berdasarkan Keputusan Menteri Kesehatan Republik Indonesia Nomor 1405/MENKES/SK/XI/2002 tentang Persyaratan Kesehatan Lingkungan Kerja
Perkantoran dan Industri terdapat pengertian mengenai air bersih yaitu air yang dipergunakan untuk keperluan seharihari dan kualitasnya memenuhi persyaratan kesehatan air bersih sesuai dengan peraturan perundang-undangan yang berlaku dan dapat diminum apabila dimasak. Sumber air bersih yang digunakan pada Rumah sakit ini berasal dari panel tank fiberglass dan roof tank. Sistem penyediaan air bersih yang digunakan adalah sistem tangki atap (roof tank). Berdasarkan KEPMEN PU No. 10 Tahun 2002, dimana setiap bangunan gedung wajib menyelenggarakan dan memenuhi ketentuan pengamanan terhadap bahaya kebakaran, sarana penyelamatan, sistem proteksi aktif, dan sistem proteksi pasif. Sistem pemadam kebakaran atau fire fighting system biasanya disediakan di gedung sebagai pencegahan (preventif) terjadinya kebakaran. Sistem ini terdiri dari sistem sprinkler, sistem hidran dan alat pemadam api ringan (APAR) atau fire extingusiher. Maka diperlukannya sistem instalasi fire fighting sebagai pencegahan dan menanggulangi terjadinya kebakaran gedung.

Permasalahan yang dibahas dalam penelitian ini adalah mengetahui berapa kebutuhan air yang harus disediakan untuk operasional harian dan air pada sistem 
pemadam kebakaran sprinkler gedung utama baru Rumah Sakit agar kebutuhan air dapat terpenuhi, dengan tujuan untuk menganalisa jumlah kebutuhan air yang harus disediakan dalam operasioanl harian dan air pada sistem pemadam kebakaran sprinkler.

\section{KAJIAN PUSTAKA}

Zurahman (2019) dengan penelitian tentang analisa kebutuhan air bersih Rumah Sakit Umum Kayu Agung Kabupaten Ogan Komering Ilir Provinsi Sumatera Selatan dengan tujuan untuk mengetahui jumlah kebutuhan air bersih untuk memenuhi kebutuhan operasional rumah sakit dengan hasil yang didapat untuk kebutuhan maksimum 166.914 liter/hari, jumlah ketersediaan air 87.750 liter/hari, kekurangan 79.164 liter/hari dan direncanakan reservoir dengan volume 198 liter.

Krisnayanti et al. (2013) melakukan penelitian dengan tujuan menghitung kebutuhan air bersih yang akan disuplai untuk merencanakan pengembangan jaringan air bersih kota kabupaten Kupang dengan hasil yang didapat untuk tahun 2021 total kebutuhan 145 liter/detik masih mampu melayani pelayanan pada 8 desa kecamatan Kupang timur. Asta (2018) Melakukan penelitian dengan judul analisa kebutuhan air bersih dan distribusi jaringan PDAM Persemaian kota tarakan dengan hasi yang didapat produksi kebutuhan air tahun 2026 sebesar 159.9374 liter/detik, kehilangan air tahun 2026 sebesar 31.9869 liter/hari dan total kebutuhan tahun 2026 sebesar 191.9216 liter/detik.

Mashuri et al. (2013) dalam Kajian Ketersediaan dan Kebutuhan Air Baku dengan Pemodelan Ihacres di Daerah Aliran Sungai Tapung Kiri menyimpulkan bahwa debit andalan dari Sungai Tapung Kiri yang digunakan sebagai sumber air baku dalam sistem penyediaan air bersih mencukupi, bahkan masih melebihi untuk memenuhi kebutuhan air bersih dari daerah layanannya sampai akhir tahun proyeksi (2035). Kebutuhan air (FJM tahun 2035) sebesar $0.395 \mathrm{~m}^{3} /$ detik masih jauh berada di bawah nilai debit minimum sebesar $43.69 \mathrm{~m}^{3} /$ detik yang terjadi pada Bulan September.

Pada perencanaan sistem penyediaan air bersih sangat diperlukan informasi mengenai sumber air, dimana nantinya sumber air tersebut dapat mencapai daerah distribusi dengan debit, tekanan dan kuantitas yang cukup dengan kualitas air sesuai dengan standar.

Sumber air bersih yang digunakan pada gedung baru Rumah Sakit ini berasal dari panel tank fiberglass dan roof tank. 
Sistem penyediaan air bersih yang digunakan adalah sistem roof tank. Sumber air ditampung panel tank fiberglass kemudian dipompakan ke dalam tangki atap. Dari tangki atap, air didistribusikan ke jaringan perpipaan dalam gedung dengan sistem gravitasi. Disamping menyediakan kebutuhan air operasional gedung, harus memperhatikan penyedian air sistem pengaman fire fighting system gedung bertingkat yang berfungsi untuk mengantisipasi munculnya bahaya kebakaran.

\subsection{Kebutuhan Air Bersih}

Kebutuhan air adalah banyaknya jumlah air yang dibutuhkan untuk keperluan rumah tangga, industri, penggelontoran kota dan lain-lain. Prioritas kebutuhan air meliputi kebutuhan air domestik, industri, pelayanan umum dan kebutuhan air untuk mengganti kebocoran (Moegijantoro, 1995).

\subsection{Kebutuhan Air Domestik}

Kebutuhan air domestik adalah kebutuhan air bersih bagi para penduduk untuk kepentingan kehidupan sehari-hari atau rumah tangga seperti untuk minum, memasak, kesehatan individu (mandi, cuci dan sebagainya), menyiram tanaman, halaman pengangkutan air buangan (buangan dapur dan toilet).

\subsection{Kebutuhan Air Non Domestik}

Menurut Kementrian Pekerjaan Umum tentang kebutuhan air maksimum, kebutuhan air non domestik merupakan kebutuhan air bagi penduduk diluar lingkungan perumahan. Kebutuhan air non domestik adalah kebutuhan air bersih yang digunakan untuk kegiatan:

1. Kebutuhan Institusional adalah kebutuhan air bersih untuk kegiatan tempat pendidikan

2. Kebutuhan Komersil adalah kebutuhan air bersih untuk kegiatan pasar, supermarket dan resrtoran

Kebutuhan air fasilitas umum adalah kebutuhan air bersih untuk kegiatan tempat-tempat ibadah, termasuk kepentingan untuk pemadam kebakaran, penyiraman dan lain-lain.

\subsection{Kebutuhan Air Sprinkler}

Sprinkler merupakan salah satu system yang digunakan untuk memadamkan kebakaran pada sebuah bangunan. Sprinkler akan secara otomatis menyala bila ada kebakaran yang terjadi. Menurut peraturan SNI (03-3998-2000) untuk bahaya kebakaran ringan penyedediaan air harus mampu mengalirkan air dengan kapasitas 225 liter/menit dan bertekanan $2.2 \mathrm{~kg} / \mathrm{cm}^{2}$ ditambah tekanan air yang ekivalen dengan 
perbedaan tinggi antara katup kendali dengan sprinkler tertinggi.

\subsection{Sistem Penyediaan Air Bersih}

Menurut Noerbambang \& Morimura (1991), saat ini penyediaan air bersih yang banyak digunakan dapat dikelompokkan meliputi sistem sambungan langsung, sistem tangki atap dan sistem tangki tekan. Sistem distribusi adalah sistem yang langsung berhubungan dengan konsumen, yang mempunyai fungsi pokok mendistribusikan air yang telah memenuhi syarat ke seluruh daerah pelayanan.

\subsection{Klasifikasi Hunian}

Klasifikasi sifat hunian harus kita pahami sebelum merencanakan untuk membangun sistem sprinkler. Klasifikasi resiko bahaya kebakaran dapat diklasifikasikan berdasar struktur bahan bangunan, banyaknya material yang tersimpan, serta sifat bahan yang tersimpan (mudah terbakar atau tidak), serta jumlah penghuni yang ada di dalamnya.

\section{METODE PENELITIAN}

\subsection{Lokasi Penelitian}

Lokasi penelitian Rumah Sakit Bahayangkara Palembang terletak di Jalan Jendral Sudirman Km 4.5 Palembang (Gambar 1).

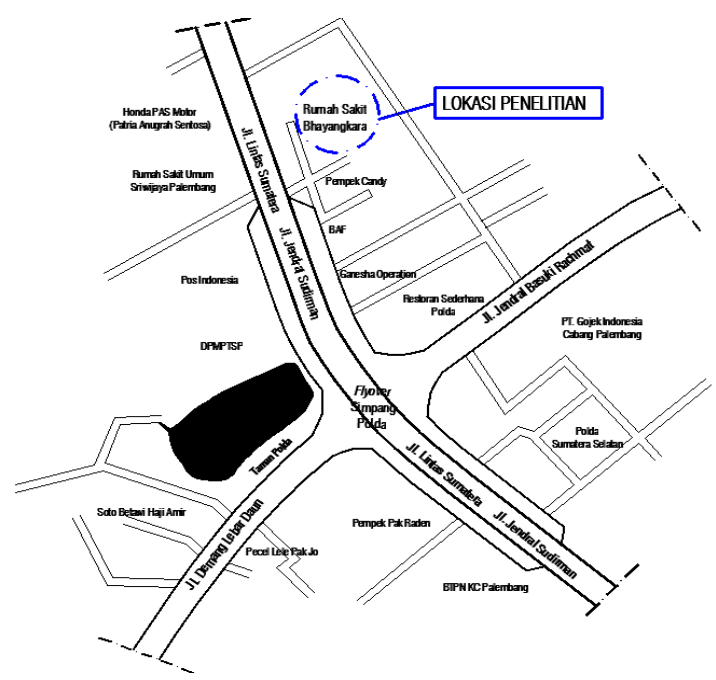

Gambar 1. Lokasi Penelitian

\subsection{Data Primer}

Merupakan data yang diperoleh dengan meninjau dan mengamati lokasi penelitian. Adapun data-data yang didapat setelah melakukan peninjauan langsung:

1. Nama rumah sakit: Rumah Sakit Bhayangkara Palembang

2. Kelas: $\mathrm{C}$

3. Alamat: Jalan Jendral Sudirman Km 4.5 Palembang

4. Luas tanah: $7538 \mathrm{~m}^{2}$

5. Luas bangunan: $6102.52 \mathrm{~m}^{2}$

6. Jumlah pegawai: 369 orang

7. Jumlah toilet: 45 buah

8. Jumlah tempat tidur: 173 buah

9. Klasifikasi hunian: hunian kebakaran ringan

10. Jumlah kepala sprinkler: 391 buah

11. Ukuran kepala sprinkler: $1 / 2$ "

12. Jenis sprinkler: pendent sprinkler 
13. Kepekaan suhu: $53^{\circ} \mathrm{C}$ dengan warna cairan dalam tabung gelas jingga

14. Area jangkauan sprinkler: 11.9 $\mathrm{m}^{2}$

15. Kepadatan pancaran: 2.25 $\mathrm{mm} / \mathrm{menit}$

16. Jarak maksimum sprinkler: 4.6 $\mathrm{m}$

17. Sumber penyimpanan air: panel tank fiberglass kapasitas $40 \mathrm{~m}^{3}$, $90 \mathrm{~m}^{3}$, dan roof tank kapasitas $16 \mathrm{~m}^{3}$.

\subsection{Data Sekunder}

Data sekunder diperoleh dari situs online yang terdiri dari data jumlah tempat tidur (Tabel 1), jumlah tenaga medis dan non medis (Tabel 2), jumlah toilet, wastafel, shower, dan peturasan (Tabel 3), jumlah titik head sprinkler (Tabel 4).

\section{Tabel 1. Jumlah Tempat Tidur}

\begin{tabular}{lc}
\hline \multicolumn{1}{c}{ Jenis Pelayanan } & Jumlah Tempat Tidur \\
\hline Rawat Inap Kelas I & 14 \\
Rawat Inap Kelas II & 12 \\
Rawat Inap Kelas IIII & 18 \\
Rawat Inap Kelas VIP & 7 \\
Rawat Inap Kelas VVIP & 3 \\
USG & 14 \\
ICU & 8 \\
Poli Anak & 8 \\
Poli Obgyn & 15 \\
Hemodialisa & 20 \\
Ruang OK Mayor & 4 \\
Ruang Bayi & 4 \\
Ruang VK & 5 \\
Total & 173 \\
\hline
\end{tabular}

Sumber: bppsdmk.kemkes.go.id
Tabel 2. Jumlah Tenaga Medis dan Non Medis

\begin{tabular}{|c|c|c|c|c|}
\hline \multicolumn{3}{|c|}{$\begin{array}{l}\text { Tenaga Medis dan Non } \\
\text { Medis }\end{array}$} & \multicolumn{2}{|c|}{ Jumlah } \\
\hline \multicolumn{3}{|l|}{ Medis } & \multicolumn{2}{|c|}{247} \\
\hline \multicolumn{3}{|c|}{ Non Medis } & \multicolumn{2}{|c|}{122} \\
\hline \multicolumn{3}{|l|}{ Total } & \multicolumn{2}{|c|}{369} \\
\hline \multicolumn{5}{|c|}{ Sumber: bppsdmk.kemkes.go.id } \\
\hline \multicolumn{5}{|c|}{$\begin{array}{c}\text { Tabel 3. Jumlah Toilet, Wastafel, Shower, } \\
\text { dan Peturasan }\end{array}$} \\
\hline Ruangan & $\begin{array}{c}\text { Jumlah } \\
\text { Toilet }\end{array}$ & $\begin{array}{c}\text { Jumlah } \\
\text { Wastafel }\end{array}$ & $\begin{array}{l}\text { Jumlah } \\
\text { Shower }\end{array}$ & $\begin{array}{c}\text { Jumlah } \\
\text { Peturasan }\end{array}$ \\
\hline $\begin{array}{l}\text { Lantai } \\
\text { dasar }\end{array}$ & 4 & 5 & 4 & 2 \\
\hline Lantai 1 & 9 & 27 & 9 & 4 \\
\hline Lantai 2 & 3 & 2 & 3 & 3 \\
\hline Lantai 3 & 29 & 28 & 29 & 3 \\
\hline Total & 45 & 62 & 45 & 12 \\
\hline
\end{tabular}

Tabel 4. Jumlah Titik Head Sprinkler

\begin{tabular}{lc}
\hline \multicolumn{1}{c}{ Ruangan } & $\begin{array}{c}\text { Jumlah Titik Head } \\
\text { Sprinkler }\end{array}$ \\
\hline Lantai Dasar & 80 \\
Lantai 1 & 103 \\
Lantai 2 & 104 \\
Lantai 3 & 104 \\
Total & 391 \\
\hline
\end{tabular}

Sumber: bppsdmk.kemkes.go.id

\subsection{Pengolahan Data}

1. Menghitung kebutuhan air

$$
\mathrm{Q}_{\mathrm{d}}=\mathrm{N} \times \mathrm{q}_{\mathrm{d}}
$$

Jumlah tempat tidur pasien $(\mathrm{N})$, kebutuhan $\mathrm{q}_{\mathrm{d}}=500$ liter $/ \mathrm{bed} / \mathrm{hari}$ (Peraturan Menteri Kesehatan RI No 7 tahun 2019). Jumlah pegawai rumah sakit $(\mathrm{N})$. Kebutuhan $\mathrm{q}_{\mathrm{d}}=120$ liter/org/hari. Jumlah toilet $\left(\mathrm{q}_{\mathrm{d}}=39\right.$ liter/hari), wastafel $\quad\left(q_{d} \quad=30\right.$ liter/hari), peturasan $\quad\left(\mathrm{q}_{\mathrm{d}} \quad=30\right.$ 
liter/hari), shower ( $q_{d}=75$ liter/hari), dan janitor $\left(q_{d}=0.5\right.$ liter $/ \mathrm{m}^{2} /$ hari $)$.

2. Menghitung kebutuhan air rata2 per hari $(\mathrm{t}=8$ jam/hari $)$

Kebutuhan air rata-rata jam kerja adalah:

$$
\mathrm{Q}_{\mathrm{h}}=\frac{\mathrm{Q}_{\mathrm{d}}}{\mathrm{t}}
$$

3. Menghitung volume ketersediaan air bersih.

4. Menentukan jenis hunian bangunan gedung.

5. Menentukan jumlah kebutuhan kepala sprinkler, SNI-03-39892000 (Q = 84.62 liter/menit, selama 30 menit).

$\mathrm{V}=\mathrm{Q} \times \mathrm{T}$

6. Menghitung kebutuhan dan ketersediaan air operasional harian dan air sistem pemadam kebakaran sprinkler.

7. Menghitung pemakaian air bersih harian maksimum.

$\mathrm{Q}_{\mathrm{hm}}=\mathrm{Q}_{\mathrm{d}} \mathrm{x} \mathrm{fhm}_{\mathrm{hm}}$

dengan:

$\mathrm{Q}_{\mathrm{d}}=$ total kebutuhan pemakaian air

$\mathrm{f}_{\mathrm{hm}}=$ faktor harian maksimum $=$ 1.1 - 1.25 (Anonim, 1997)

8. Menghitung pemakaian air bersih jam puncak

$\mathrm{Q}_{\mathrm{jm}}=\mathrm{Q}_{\mathrm{h}} \mathrm{X} \mathrm{f}_{\mathrm{jm}}$
$\mathrm{Q}_{\mathrm{h}}=$ pemakaian air harian

maksimum

$\mathrm{f}_{\mathrm{jm}}=$ faktor $\mathrm{jam}$ puncak $=2,0$

(Anonim, 1997)

9. Menentukan daya pompa yang akan digunakan untuk alat pemadam kebakaran.

\section{HASIL DAN PEMBAHASAN}

\subsection{Kebutuhan Air Tempat Tidur}

Ruang rawat inap kelas I, dimana jumlah tempat tidur $(\mathrm{N})$ adalah 14 bed. Kebutuhan air $\left(\mathrm{q}_{\mathrm{d}}\right)$ adalah 500 liter/bed/hari, sehingga:

$$
\begin{aligned}
\mathrm{Q}_{\mathrm{d}} & =\mathrm{N} \times \mathrm{q}_{\mathrm{d}} \\
& =14 \text { bed } \times 500 \text { liter/bed/hari } \\
& =7000 \text { liter/hari }
\end{aligned}
$$

Tabel 5. Kebutuhan Air Bersih Tempat Tidur

\begin{tabular}{lc}
\hline \multicolumn{1}{c}{ Jenis Pelayanan } & $\begin{array}{c}\text { Kebutuhan Air } \\
\text { (liter/hari) }\end{array}$ \\
\hline Rawat Inap Kelas I & 7000 \\
Rawat Inap Kelas II & 6000 \\
Rawat Inap Kelas IIII & 9000 \\
Rawat Inap Kelas VIP & 3500 \\
Rawat Inap Kelas VVIP & 1500 \\
USG & 7000 \\
ICU & 4000 \\
Poli Anak & 4000 \\
Poli Obgyn & 7500 \\
Hemodialisa & 10000 \\
Ruang OK Mayor & 2000 \\
Ruang Bayi & 2000 \\
Ruang VK & 2500 \\
Total & 66000 \\
\hline
\end{tabular}




\subsection{Kebutuhan Air Pegawai}

Tabel 6. Kebutuhan Air Pegawai

\begin{tabular}{lcc}
\hline $\begin{array}{c}\text { Tenaga Medis } \\
\text { dan Non Medis }\end{array}$ & $\begin{array}{c}\text { Jumlah } \\
\text { Tenaga }(\mathrm{N})\end{array}$ & $\begin{array}{c}\text { Kebutuhan Air } \\
\text { (liter/hari) }\end{array}$ \\
\hline Medis & 247 & 29640 \\
Non Medis & 122 & 14640 \\
Total & 369 & 44280 \\
\hline
\end{tabular}

\subsection{Kebutuhan Air Toilet}

Tabel 7. Kebutuhan Air untuk Toilet

\begin{tabular}{lcc}
\hline \multicolumn{1}{c}{ Ruangan } & $\begin{array}{c}\text { Jumlah } \\
\text { Toilet }\end{array}$ & $\begin{array}{c}\text { Kebutuhan Air } \\
\text { (liter/hari) }\end{array}$ \\
\hline Lantai dasar & 4 & 156 \\
Lantai 1 & 9 & 351 \\
Lantai 2 & 3 & 117 \\
Lantai 3 & 29 & 1131 \\
Total & 45 & 1755 \\
\hline
\end{tabular}

\subsection{Kebutuhan Air Wastafel}

Tabel 8. Kebutuhan Air Wastafel

\begin{tabular}{lcc}
\hline \multicolumn{1}{c}{ Ruangan } & $\begin{array}{c}\text { Jumlah } \\
\text { Wastafel }\end{array}$ & $\begin{array}{c}\text { Kebutuhan Air } \\
\text { (liter/hari) }\end{array}$ \\
\hline Lantai dasar & 5 & 150 \\
Lantai 1 & 27 & 810 \\
Lantai 2 & 2 & 60 \\
Lantai 3 & 28 & 840 \\
Total & 62 & 1860 \\
\hline
\end{tabular}

\subsection{Kebutuhan Air Peturasan}

Untuk lantai dasar, jumlah peturusan $\mathrm{N}=2$, kebutuhan air $\left(\mathrm{q}_{\mathrm{d}}\right)=10$ liter/ kali/hari $=30$ liter/3kali/hari. Maka:

$$
\begin{aligned}
Q_{\mathrm{d}} & =2 \times 30 \\
& =60 \text { liter/hari }
\end{aligned}
$$

Tabel 9. Kebutuhan Air Peturasan

\begin{tabular}{lcc}
\hline \multicolumn{1}{c}{ Ruangan } & $\begin{array}{c}\text { Jumlah } \\
\text { Peturasan }\end{array}$ & $\begin{array}{c}\text { Kebutuhan Air } \\
\text { (liter/hari) }\end{array}$ \\
\hline Lantai dasar & 2 & 60 \\
Lantai 1 & 4 & 120 \\
Lantai 2 & 3 & 90 \\
Lantai 3 & 3 & 90 \\
Total & 12 & 360 \\
\hline
\end{tabular}

\subsection{Kebutuhan Air Shower}

Tabel 10. Kebutuhan Air Shower

\begin{tabular}{lcc}
\hline \multicolumn{1}{c}{ Ruangan } & $\begin{array}{c}\text { Jumlah } \\
\text { Shower }\end{array}$ & $\begin{array}{c}\text { Kebutuhan Air } \\
\text { (liter/hari) }\end{array}$ \\
\hline Lantai dasar & 4 & 300 \\
Lantai 1 & 9 & 675 \\
Lantai 2 & 3 & 225 \\
Lantai 3 & 29 & 2175 \\
Total & 12 & 3375 \\
\hline
\end{tabular}

\subsection{Kebutuhan Air untuk Janitor}

Luas gedung utama baru $=6102.52$ $\mathrm{m}^{2}$, dimana kebutuhan $\left(\mathrm{q}_{\mathrm{d}}\right)$ adalah 0.5 liter $/ \mathrm{m}^{2} /$ hari, sehingga kebutuhan air $\left(\mathrm{Q}_{\mathrm{d}}\right)$ adalah:

$$
\begin{aligned}
Q_{d} & =6102.52 \mathrm{~m}^{2} \times 0.5 \text { liter } / \mathrm{m}^{2} / \text { hari } \\
& =3051.26 \text { liter } / \text { hari }
\end{aligned}
$$

\subsection{Total Kebutuhan Air Rumah Sakit}

Tabel 11. Kebutuhan Air Rumah Sakit

\begin{tabular}{lc}
\hline Jenis Pemakaian & $\begin{array}{c}\text { Kebutuhan Air } \\
\text { (liter/hari) }\end{array}$ \\
\hline Tempat Tidur & 66000 \\
Pegawai & 44280 \\
Toilet & 1755 \\
Wastafel & 1860 \\
Paturasan & 360 \\
Shower & 3375 \\
Janitor & 3051.26 \\
Total & 120681.26 \\
\hline
\end{tabular}

\subsection{Pemakaian Air Rata-Rata dalam Sehari $\left(Q_{h}\right)$}

Jangka waktu pemakaian air rata-rata dalam sehari untuk rumah sakit $=8$ jam/hari (Noerbambang \& Morimura, 1991). Kebutuhan air rata-rata jam kerja adalah sebagai berikut: 


$$
\begin{aligned}
& \mathrm{Q}_{\mathrm{h}}=\frac{\mathrm{Q}_{\mathrm{d}}}{\mathrm{t}} \\
& \mathrm{Q}_{\mathrm{h}}=\frac{120681.26 \text { liter } / \text { hari }}{8 \mathrm{jam} / \text { hari }} \\
& \mathrm{Q}_{\mathrm{h}}=15085.16 \text { liter } / \mathrm{jam}
\end{aligned}
$$

\subsection{Kebutuhan Air Bersih untuk Keadaan Darurat Bangunan (Sprinkler)}

Menghitung kebutuhan air bersih sprinkler gedung utama lantai dasar. Menurut peraturan SNI-03-3989-2000 sprinkler dengan sistem terbuka membutuhkan debit air (Q) = 84.62 liter/menit. serta mampu mengalirkan air selama 30 menit untuk kategori kebakaran ringan.

$$
\begin{aligned}
\mathrm{V} & =\mathrm{Q} \times \mathrm{T} \\
\mathrm{Q} & =84.62 \text { liter/menit } \\
& =1410 \text { liter/detik } \\
\mathrm{T} & =30 \text { menit }=1800 \text { detik } \\
\mathrm{V} & =1410 \text { liter/detik } \times 1800 \text { detik } \\
& =2538 \text { liter }
\end{aligned}
$$

Total volume untuk jumlah 80 titik sprinkler adalah:

$$
\begin{aligned}
80 \text { titik sprinkler } & =80 \times \mathrm{V} \\
& =80 \times 2538 \text { liter } \\
& =203040 \text { liter }
\end{aligned}
$$

Tabel 12. Kebutuhan Air Sprinkler

\begin{tabular}{lc}
\hline \multicolumn{1}{c}{ Ruangan } & $\begin{array}{c}\text { Kebutuhan Air } \\
\text { (liter/hari) }\end{array}$ \\
\hline Lantai dasar & 203040 \\
Lantai 1 & 261414 \\
Lantai 2 & 263952 \\
Lantai 3 & 263952 \\
Total & 992358 \\
\hline
\end{tabular}

Tabel 13. Rekapitulasi Kebutuhan Air Operasional Harian

\begin{tabular}{lc}
\hline Jenis Kebutuhan Air & $\begin{array}{c}\text { Kebutuhan Air } \\
\text { (liter/hari) }\end{array}$ \\
\hline Operasional Harian & 120681.26 \\
Sprinkler & 992358 \\
Total & 1113039.26 \\
\hline
\end{tabular}

\subsection{Ketersediaan Air}

Sumber air bersih di Rumah Sakit Bhayangkara Palembang berasal dari PDAM kemudian ditampung pada panel tank fiberglass berkapasitas $40 \mathrm{~m}^{3}$, panel tank fiberglass berkapasitas $90 \mathrm{~m}^{3}$, dan roof tank berkapasitas $16 \mathrm{~m}^{3}$. Total volume penampungan adalah $40 \mathrm{~m}^{3}+90 \mathrm{~m}^{3}+$ $16 \mathrm{~m}^{3}=146 \mathrm{~m}^{3}=146000$ liter.

\subsection{Pemakaian Air Bersih Pada Harian Maksimum dan Pada Jam Puncak}

1. Pemakaian air pada harian maksimum

$$
\begin{aligned}
& Q_{h m}=Q_{d} \times f_{h m} \\
& Q_{d}=120681.26 \text { liter/hari } \\
& \left(f_{h m}\right) \text { faktor harian maksimum } \\
& 1.1-1.25 \\
& \begin{aligned}
Q_{h m} & =120681.26 \times 1.1 \\
& =132749 \text { liter } / \text { hari } \\
& =133 \mathrm{~m}^{3} / \text { hari }
\end{aligned}
\end{aligned}
$$

(fhm) faktor harian maksimum $=$

2. Pemakaian air pada jam puncak

$\mathrm{Q}_{\mathrm{jm}}=\mathrm{Q}_{\mathrm{h}} \times \mathrm{f}_{\mathrm{jm}}$

$\left(f_{j m}\right)$ faktor jam puncak $=2.0$

$$
\begin{aligned}
Q_{j m} & =133 \mathrm{~m}^{3} / \text { hari } \times 2.0 \\
& =266 \mathrm{~m}^{3} / \text { hari }
\end{aligned}
$$




\subsection{Perhitungan Penambahan 20\% dari Total Kebutuhan untuk Mengantisipasi Kebocoran Air}

Hasil perhitungan total kebutuhan air bersih maksimum adalah $133 \mathrm{~m}^{3} /$ hari sedangkan jumlah ketersediaan air bersih adalah $146 \mathrm{~m}^{3} /$ hari. Maka ketersediaan air untuk kebutuhan air maksimum sudah mencukupi. Untuk mengantisipasi kebocoran pipa maka dilakukan penambahan $20 \%$ dari total kebutuhan air:

$$
\begin{aligned}
\mathrm{V} & =133+(20 \% \times 133) \mathrm{m}^{3} / \text { hari } \\
& =160 \mathrm{~m}^{3} / \text { hari }
\end{aligned}
$$

Kekurangan air $=(146-160) \mathrm{m}^{3} /$ hari

$$
=14 \mathrm{~m}^{3} / \text { hari }
$$

Maka untuk mengatasi kekurangan tersebut dapat ditambah roof tank kapasitas 15.000 liter $\left(15 \mathrm{~m}^{3}\right)$ dengan dimensi panjang: $3 \mathrm{~m}$, lebar: $2 \mathrm{~m}$, dan tinggi: $2.5 \mathrm{~m}$

Kebutuhan air sistem pemadam kebakaran sprinker selama 30 menit adalah 992.358 liter $=992.4 \mathrm{~m}^{3}$ dengan ketersediaan air $146 \mathrm{~m}^{3}$ tidak mampu mencukupi kebutuhan air sistem pemadam kebakaran sprinkler jika terjadi kebakaran. Untuk mengantisipasi kebocoran pipa maka ditambahkan 20\% dari kebutuhan air sistem pemadam kebakaran sprinkler.

$$
\begin{aligned}
\mathrm{V} & =992.4+(20 \% \times 992.4) \mathrm{m}^{3} \\
& =1190 \mathrm{~m}^{3}
\end{aligned}
$$

Untuk mengantisipasi kekurangan air dan datangnya mobil pemadam kebakaran diperlukan tambahan penyimpanan air (ground water tank), serta pemasangan sistem fire alarm full addressable yang berfungsi mendeteksi sesuai titik terjadinya kebakaran dan dapat dipantau dengan control panel fire alarm sehingga kita dapat dengan mudah melakukan tindakan ke titik masalah kebakaran. Adapun ukuran ground tank yang direncanakan kapasitas $1250 \mathrm{~m}^{3}$, dengan dimensi panjang: $25 \mathrm{~m}$, lebar: $5 \mathrm{~m}$, dan tinggi: $10 \mathrm{~m}$.

\section{SIMPULAN DAN SARAN}

\subsection{Simpulan}

1. Kebutuhan air bersih harian maksimum Rumah Sakit Bhayangkara Palembang adalah $133 \mathrm{~m}^{3} /$ hari.

2. Kebutuhan air sistem pemadam kebakaran sprinkler selama 30 menit adalah $992.4 \mathrm{~m}^{3} /$ hari.

3. Kebutuhan air operasional harian dan air pada sistem pemadam kebakaran sprinkler adalah 1113039.26 liter/hari atau $1113.04 \mathrm{~m}^{3} /$ hari

4. Sedangkan kapasitas penyimpanan air bersih Rumah Sakit Bhayangkara Palembang adalah $146 \mathrm{~m}^{3}$. 


\subsection{Saran}

Perlu penambahan roof tank dan ground water tank sebagai tempat penyimpanan air untuk memenuhi kebutuhan operasional air rumah sakit.

\section{DAFTAR PUSTAKA}

Anonim. (1995). SNI 03-3987-1995 tentang Tata Cara Perencanaan, Pemasangan, Pemadam Api Ringan Untuk Pencegahan Bahaya Kebakaran Pada Bangunan dan Gedung. Jakarta: Badan Stadardisasi Nasional.

Anonim. (1997). Kriteria Perencanaan Air Bersih. Jakarta: Ditjen Cipta Karya Dinas PU.

Anonim. (2000a). SNI 03-1745-2000 tentang Tata Cara Perencanaan dan Pemasangan Sistem Pipa Tegak dan Slang Untuk Pencegahan Bahaya Kebakaran Pada Bangunan Rumah dan Gedung. Jakarta: Badan Stadardisasi Nasional.

Anonim. (2000b). SNI 03-3989-2000 tentang Tata Cara Perencanaan Dan pemasangan Sistem Sprinkler Otomatik untuk Pencegahan Bahaya Kebakaran Pada Bangunan Gedung.

Anonim. (2008). Peraturan Menteri Pekerjaan Umum No. 26/PRT/M/2008 tentang Persyaratan Teknis Sistem Proteksi Kebakaran Pada Bangunan Gedung dan Lingkungan. Jakarta: Menteri Pekerjaan Umum.

Asta. (2018). Analisis Kebutuhan Air Bersih dan Distribusi Jaringan PDAM Persemaian Kota Tarakan (Studi Kasus Kecamatan Tarakan Barat). Borneo Engineering: Jurnal Teknik Sipil, 2(1), 61-68.
Azrie, M. I. (2018). Analisa Kebutuhan Air Bersih untuk Hydrant dan Sprinkler di Transmart Mall Palembang. Universitas Muhammadiyah Palembang.

Fadhil, M. A. (2018). Analisa Kebutuhan Air Bersih di Rumah Sakit Umum Daerah OKU Timur, Provinsi Sumatera Selatan. Universitas Muhammadiyah Palembang.

http://bppsdmk.kemkes.go.id/info_sdmk/in fo/fasyankes?unit=1671331

Krisnayanti, D. S., Udiana, I M., \& Benu, H. J. (2013). Studi Perencanaan Pengembangan Penyediaan Air Bersih di Kecamatan Kupang Timur Kabupaten Kupang. Jurnal Teknik Sipil, II (1), 71-86.

Mashuri, Fauzi, M., \& Sandhyavitri, A. (2013). Kajian Ketersediaan dan Kebutuhan Air Baku dengan Pemodelan IHACRES di Daerah Aliran Sungai Tapung Kiri. Jom FTEKNIK, 2(1), 1-12.

Moegijantoro. (1995). Air Untuk Kehidupan Manusia. Majalah Air Minum, XXV (85).

Noerbambang, M. S., \& Morimura, T. (1991). Perancangan dan Pemeliharaan Sistem Plambing (Cetakan Keempat). Jakarta: PT Pradnya Paramita.

Sularso, H. T. (2000). Pompa dan Kompresor (Cetakan Ketujuh). Jakarta: PT Pradnya Paramita.

Zurahman, H. (2019). Analisa Kebutuhan Air Bersih Di Rumah Sakit Umum daerah Kayu Agung Kabupaten Ogan Komering Ilir Provinsi Sumatera Selatan. Universitas Muhammadiyah Palembang. 